\title{
„Ég held ég hafi bara ekki vitað hvað hamingja var áður en pau fæddust": Upplifun feðra af hamingju
}

\author{
Pála Margrét Gunnarsdóttir, \\ Ingibjörg V. Kaldalóns og Hrund Dórarins Ingudóttir \\ Abstract $>$ Um höfunda $>$ About the authors $>$ Heimildir
}

Lítið er um rannsóknir á áhrifum barneigna og barnauppeldis á hamingju feðra. Markmið pessarar rannsóknar var að öðlast aukinn skilning á hvernig feður upplifa hamingju við að eignast og eiga börn. Fyrirbærafræðilegri nálgun var beitt, par sem tekin voru opin viðtöl við níu feður. Beir áttu tvö til prjú börn, 13 ára eða yngri, og bjuggu allir með barnsmóður sinni. Upplifun feðranna á hamingju var skoðuð út frá premur kenningum um hamingju; kenningu um jákvæðar tilfinningar, sjálfsákvörðunarkenningu um farsæld og sálrænar grunnparfir, og kenningu um hamingju út frá auknum lífstilgangi. Niðurstöður rannsóknarinnar sýndu að feðurnir upplifðu hamingjuna á annan hátt eftir að peir eignuðust börn. Deir upplifðu meira af jákvæðum tilfinningum; djúpstæðri ást, gleði og pakklæti eftir að peir eignuðust börnin en ádur. Feðurnir tengdu hamingjuna pví að hve miklu leyti peir gætu ráđið sér sjálfir, hversu hæfir peir töldu sig vera til að sinna foreldrahlutverkinu og hvernig peir tengdust börnunum. Einnig lýstu peir auknum lífstilgangi eftir að peir eignuðust börnin og að hamingjan yrði merkingarbærri og innihaldsríkari. Drátt fyrir að lífið með börnunum veitti peim hamingju töldu peir pað líka krefjandi og að mörgu leyti erfiðara en áður, par sem peir leituðust við að sinna uppeldi, samræma vinnu og fjölskyldulíf og hafa tíma fyrir maka, vini og áhugamál. Í heildina virtist pað pó engu máli skipta í samanburði við pá hamingju sem börnin veittu peim. Ekki er vitað til pess að hamingja feðra hafi verið rannsökuð með pessum hætti áður. Rannsóknin er mikilvægt framlag til rannsókna á hamingju innan jákvæðrar sálfræði sem og rannsókna á upplifun feðra af hlutverki sínu.

Efnisorð: Hamingja, hamingjukenningar, feður, föðurhlutverkið, fyrirbærafræði

\section{Inngangur}

Markmið pessarar greinar er að varpa ljósi á hvernig upplifun feðra af hamingju breytist við að eignast og eiga börn. Margir telja að börn auki hamingju foreldra sinna og séu grunnurinn að innihaldsríku lífi (Hansen, 2012; Margolis og Myrskylä, 2011). Í fyrri rannsóknum hafa pau áhrif sem foreldrar hafa á börn sín meira verið skoðuð (sjá t.d. Borisenko, 2007; Palkovitz o.fl., 2003) en pau áhrif sem börn hafa á foreldra sína. Đá hefur móðurhlutverkið fengið meiri athygli en föðurhlutverkið í rannsóknum (Luhmann o.fl., 2012; Thompson o.fl., 2013). Föðurhlutverkið hefur breyst mikið síðustu áratugi og flestir feður nú á dögum vilja taka virkan pátt í uppeldishlutverkinu (Ásta Jóhannsdóttir og Ingólfur V. Gíslason, 2018; Hrund Dórarins Ingudóttir, 2015). Dví er mikilvægt að varpa ljósi á sýn feðra og upplifun peirra af föðurhlutverkinu. Dó vísbendingar séu um að feður upplifi mikla lífshamingju í hlutverki sínu (Nelson-Coffey o.fl., 2019) er ósamræmi í niðurstöðum rannsókna á hamingju foreldra. Sumar rannsóknir sýna að barneignir auki hamingju foreldra (Nelson o.fl., 2013) en aðrar að barneignir geti dregið úr hamingju peirra (Margolis og Myrskylä, 2011). 
Dað að eiga börn hefur jákvæð áhrif á hamingju feðra. Feður upplifa meiri hamingju en barnlausir karlmenn (Balbo og Arpino, 2016; Nelson o.fl., 2013; Nelson-Coffey o.fl., 2019). Fjöldi barna getur einnig haft áhrif á hamingju feðra (Aassve o.fl., 2012; Kohler o.fl., 2005). Til dæmis eru feður sem eiga tvö til prjú börn talsvert líklegri til að segjast vera mjög hamingjusamir en feður sem eiga eitt barn, á meðan feður sem eiga eitt barn segjast vera álíka hamingjusamir og barnlausir karlmenn (Baranowska og Matysiak, 2011). Feður upplifa einnig meiri hamingju en mæður (Balbo og Arpino, 2016; Nelson o.fl., 2013; Nelson-Coffey o.fl., 2019) en pað gæti verið vegna pess að mæður finna fyrir meira álagi í tengslum við foreldrahlutverkið en feður (Aassve o.fl., 2012; Andrea Hjálmsdóttir og Valgerður S. Bjarnadóttir, 2021; Nelson-Coffey o.fl., 2019). Mæður verja meiri tíma einar með börnum sínum og sinna oftar almennri umönnun barna en feður (Craig, 2006; Musick o.fl., 2016). Feður eru aftur á móti líklegri til að verja tíma með börnum sínum í tómstundum og leik, tíma sem einkennist af ánægju og er laus við streitu (Musick o.fl., 2016).

Margir aðrir pættir en að eignast og eiga börn geta haft áhrif á hamingju fólks, svo sem hjúskaparstaða, félagslegur stuðningur og fjárhagslegt öryggi. Einstaklingar í hjónabandi eru hamingjusamari en peir sem ekki eru í hjónabandi (Myers og Diener, 2018; Nelson-Coffey, 2018). Dá virðist hjónaband hafa jákvæðari áhrif á hamingju karla en kvenna (Kohler o.fl., 2005; Nelson-Coffey, 2018). Einstaklingar sem upplifa félagslegan stuðning frá fjölskyldu og vinum eru líklegir til að vera hamingjusamari en aðrir (Helliwell o.fl., 2017; Siedlecki o.fl., 2014). Рað sama á við um einstaklinga sem búa við fjárhagslegt öryggi (Dóra Guðrún Guðmundsdóttir, 2013).

Dá er líklegt að pað félagslega og menningarlega umhverfi sem feður lifa í, hafi áhrif á hamingju peirra. Til dæmis skiptir meira máli fyrir hamingju karlmanna hversu ánægðir peir eru með fjölskyldulíf sitt ef peir búa í löndum par sem ríkir mikið kynjajafnrétti, heldur en ef peir búa í löndum par sem kynjahlutverkin eru íhaldssöm (Nordenmark, 2018). Баð gæti pví haft jákvæð áhrif á hamingju feđra að búa par sem virk pátttaka peirra í uppeldi barna sinna er samfélagslega sampykkt, eins og raunin er hér á landi. Á Íslandi mælist kynjajafnrétti hvað mest í heiminum (World Economic Forum, 2021). Degar rannsóknin var gerð áttu feður rétt á premur óframseljanlegum mánuðum til fæðingarorlofs og premur til viðbótar sem peir gátu deilt með barnsmóður (lög um fæðingar- og foreldraorlof nr. 95/2000). Pá sýna rannsóknir hér á landi að pátttaka feðra í umönnun barna sinna er að aukast (Ásdís Aðalbjörg Arnalds o.fl., 2013, 2015; Dóra Kristín Dórisdóttir og Kolbeinn Stefánsson, 2010). Allt petta er líklegt til að hafa áhrif á upplifun íslenskra feðra af hamingju.

Íslendingar mælast meðal hamingjusömustu pjóða heims (Helliwell o.fl., 2021) og pví má álykta að íslenskir feður séu hamingjusamir. Aftur á móti hafa afar fáar rannsóknir verið gerðar á hamingju foreldra hér á landi. Komið hefur fram í rannsóknum Dóru Guðrúnar Guðmundsdóttur að foreldrar séu jafn hamingjusamir og barnlaust fólk (Eiríkur Ingi Björnsson og Sigríður Halldórsdóttir, 2017) en í öđrum rannsóknum að foreldrar séu hamingjusamari en barnlaust fólk (Maskína, 2019). Pá hafa engar rannsóknir verið gerðar hér á landi á hamingju feðra, svo vitað sé. Gildi rannsóknarinnar felst 1 auknum skilningi á hvernig feður upplifa hamingju við að eignast og eiga börn.

\section{Hamingja í foreldrahlutverkinu}

Ekki eru allir á einu máli um í hverju hamingja (e. happiness) felst. Ýmsar kenningar og skilgreiningar hafa verið settar fram sem í grunninn byggjast á tveimur meginsjónarhornum; annars vegar er litið á hamingju sem sceld (e. hedonia) og hins vegar er litið á hana sem farsæld (e. eudaimonia) (Ryan o.fl., 2013). Hér verður gerð grein fyrir peim premur hamingjukenningum úr smiðju jákvæðrar sálfræði sem birtust skýrast í viðtölum við feðurna. Í fyrsta lagi er pað kenningin um jákvæðar tilfinningar (e. positive emotions), sem er byggð á sældarhyggjunni. Í öđru lagi er svo sjálfsákvörðunarkenningin (e. self-determination theory) um sálrænar grunnparfir 
(e. basic need theory) og loks er pað kenningin um lífstilgang (e. meaning in life), en báðar pessar síðarnefndu falla undir sjónarhorn farsældarhyggjunnar.

\section{Hamingja sem ánægja}

Samkvæmt kenningu um jákvoeðar tilfinningar felst hamingjan í hvernig okkur líður pá og pá stundina. Átt er við tilfinningar á borð við ánægju, gleði, stolt og pað að njóta (Fredrickson, 2009). Hamingja er pá mæld með huglægu mati einstaklingsins á hversu vel eða illa honum líður (Ryan og Deci, 2001). Í sálfræðirannsóknum sem byggjast á sældarhyggju er reynt að mæla hlutfall jákvæðra og neikvæðra tilfinninga á tilteknu tímabili til pess að meta hamingju einstaklinga (Diener o.fl., 2009). Rannsóknir Fredrickson (2009) á áhrifum tilfinninga sýna að jákvæðar tilfinningar ýta undir prautseigju, umburðarlyndi og úrræðasemi og minnka áhrif neikvæðra tilfinninga.

Tilfinningar tengdar foreldrahlutverkinu hafa bæði jákvæð og neikvæð áhrif á hamingju foreldra samkvæmt líkani Nelson og félaga (2014). Safngreining (e. meta-analysis) Luhmann og félaga (2012) sýndi að jákvæðar tilfinningar fólks jukust eftir að pað eignaðist sitt fyrsta barn og héldust pannig að minnsta kosti fyrstu ár barnsins. Aðrar rannsóknir hafa borið saman foreldra og barnlaust fólk. Dær sýna að í daglegu lífi upplifa foreldrar fleiri jákvæðar tilfinningar en barnlaust fólk (Deaton og Stone, 2014). Sem dæmi geta foreldrar fundið fyrir stolti og gleði við að sjá börnin sín proskast og dafna (Nelson o.fl., 2014). Að auki upplifa foreldrar fleiri jákvæðar tilfinningar pegar peir verja tíma með börnum sínum en í öðrum daglegum athöfnum (Musick o.fl., 2016; Nelson o.fl., 2013). Dessar jákvæðu tilfinningar stuðla að hamingju foreldra (Diener o.fl., 1998; Fredrickson, 2009). Um leið benda rannsóknir til pess að í daglegu lífi upplifi foreldrar fleiri neikvæðar tilfinningar en barnlaust fólk (Deaton og Stone, 2014). Ástæða pess er sú að foreldrahlutverkinu fylgir oft streita, álag og áskoranir (Hansen, 2012; Knee og Uysal, 2011). Dá getur sú mikla ábyrgð sem fylgir pví að vera foreldri aukið áhyggjur, kvíða og hræðslu (Nelson o.fl., 2014). Foreldrar geta til dæmis haft áhyggjur af að eitthvað komi fyrir börn peirra (Stickler o.fl., 1991) og verið óöruggir um hvernig peir eigi að sinna uppeldi barna sinna (Bornstein, 2019). Foreldrahlutverkinu fylgja pví bæði auknar jákvæðar tilfinningar og auknar neikvæðar tilfinningar, sem gerir pað að verkum að flókið er að meta áhrif barna á hamingju foreldra. Auk tilfinninganna getur foreldrahlutverkinu fylgt svefnleysi og preyta, fjárhagslegt álag og álag á parsambandið, sem einnig hefur áhrif á hamingju foreldra (Nelson o.fl., 2014).

Að skilgreina hamingju út frá jákvæðum tilfinningum, eða ánægju, hefur ýmsa kosti, svo sem að vera bæði skýrt og mælanlegt (Ryan o.fl., 2008). Fræðimenn hafa pó bent á að hamingja sé flóknara fyrirbæri en svo, að nóg sé að skilgreina hana sem ánægju (Diener o.fl., 1998; Ryan o.fl., 2008). Einstaklingur getur sem dæmi upplifað mikla ánægju í lífi sem einkennist af efnishyggju, græðgi og pví að notfæra sér fólk. Đað er ekki talið endurspegla hið hamingjuríka líf vegna pess að pví meira sem fólk leitast við að hámarka eigin ánægju og forðast erfiðleika, peim mun líklegra er pað til að skapa sér líf sem skortir dýpt, tilgang og tengsl við annað fólk (Ryan o.fl., 2008). Ryan og Deci (2011) hafa einnig bent á að getan til að upplifa neikvæðar tilfinningar, eins og sorg eftir missi, geti oft verið birtingarmynd hamingju og heilbrigðis. Aftur á móti er pað að fela neikvæðar tilfinningar með jákvæðum tilfinningum að peirra mati ekki birtingarmynd hamingju. Jákvæðar tilfinningar, eða ánægja, eru pví ekki taldar fullnægjandi skilgreining á hamingju. Flestar rannsóknir sem hafa verið gerðar á hamingju foreldra hingað til hafa byggst á sældarhyggju en færri varpað ljósi á farsældina, eins og gert er í pessari rannsókn.

\section{Hamingja pegar sálrænum grunnpörfum er mætt}

Sjálfsákvörðunarkenningin um sálrænar grunnparfir er ein helsta farsældarkenning sálfræðinnar nú á dögum. Samkvæmt henni er manneskjunni nauðsynlegt að fá sálrænum grunnpörfum sínum fullnægt til að lifa farsælu lífi (Ryan og Deci, 2000, 2011, 2017, 2019). Sálrænu grunnparfirnar 
eru prjár: 1) Dörfin fyrir sjálfræði, pað er að ráđa sér sjálfur og athafna sig samkvæmt eigin sannfæringu; 2) pörfin fyrir félagstengsl, pað er að finna fyrir nánum tengslum við annað fólk og finnast maður vera mikilvægur hluti af samfélaginu; og 3) pörfin fyrir hæfni, pað er að upplifa árangur og leikni í pví sem maður tekur sér fyrir hendur (Ingibjörg Kaldalóns, 2015; Ryan og Deci, 2017, 2019). Degar pessum grunnpörfum er fullnægt stuðlar раð аð aukinni hamingju, proska, árangri, virkni og góðri andlegri heilsu (Ryan og Deci, 2014). Ef pessum grunnpörfum er aftur á móti ekki mætt, getur pað dregið úr hamingju og haft neikvæð áhrif á líkamlega og andlega heilsu (Deci og Ryan, 2000; Ryan og Deci, 2011). Nóg er að einni af grunnpörfunum sé ekki fullnægt til að pað hafi neikvæð áhrif á líf fólks (Ryan og Deci, 2014).

Ásamt að fá grunnpörfum sínum fullnægt felst farsældin einnig í að lifa meðvituðu lífi í samræmi við eigin gildi og markmið. Til að pað sé mögulegt parf hin farsæla manneskja að ígrunda eigin athafnir og parfir og verða pannig meðvituð um eigið líf (Ryan o.fl., 2008, 2013; Ryan og Deci, 2019). Hið farsæla líf er pví ekki tilfinning heldur forskrift að lífi sem leiðir af sér hamingju. Рað er pannig víðari nálgun en að skilgreina hamingju sem ánægju eða út frá jákvæðum tilfinningum (Ryan o.fl., 2008, 2013).

Rannsóknir á upplifun foreldra af pví hvernig peir fá sálrænum grunnpörfum sínum fullnægt eru mjög takmarkaðar. Nelson og félagar (2014) hafa pó bent á að barneignir auki líkurnar á að foreldrar fái grunnpörfum sínum fullnægt. Nýleg rannsókn Nelson-Coffey og félaga (2019) sýnir jafnframt að foreldrar upplifa meira sjálfræði en barnlaust fólk. Par kemur einnig fram að feður upplifa meiri félagstengsl en barnlausir karlar, á meðan mæður og barnlausar konur upplifa jafn mikil félagstengsl. Rannsóknin er sú eina sem vitað er til að skoði tengsl foreldrahlutverksins og sálrænna grunnparfa og pví er pörf á frekari rannsóknum á pessu sviði.

\section{Hamingja sem lífstilgangur}

Kenningin um hamingju út frá lífstilgangi er sú síðari af tveimur kenningum í anda farsældarhyggjunnar sem hér er fjallað um. Lífstilgangur er meginpáttur í hinu farsæla lífi. Fólki sem upplifir lífstilgang finnst líf sitt vera eins og pað á að vera, upplifir skýra stefnu í eigin lífi og finnst gjörðir sínar skipta máli (George og Park, 2016; Martela og Steger, 2016). Martela og Steger (2016) útskýra lífstilgang út frá premur hugtökum; 1) samhengi (e. coherence), pví að upplifa líf sitt sem skiljanlegt og skilmerkilegt; 2) lífsstefnu (e. purpose), pví að stefna að einhverju í lífinu og hafa framtíðarmarkmið í samræmi við pað; og 3) merkingarbæru lífi (e. significance), pví að upplifa líf sitt sem mikilvægt og dýrmætt og að lífið sé pess virði að lifa pví. Saman mynda pessir prír pættir hamingju í formi aukins lífstilgangs.

Rannsóknir hafa einnig sýnt fram á tengsl sálrænna grunnparfa og lífstilgangs. Rannsókn Martela, Ryan og Steger (2017) leiddi í ljós að mikilvægt væri að fá sálrænum grunnpörfum sínum fullnægt til pess að upplifa lífstilgang. Dar eru félagstengslin talin skipta mestu máli, pað er að segja að tengjast öðrum nánum böndum og tilheyra. Rannsóknir hafa jafnframt sýnt að pað að eiga fjölskyldu sé eitt af pví sem stuðli hvað mest að upplifun lífstilgangs (Lambert o.fl., 2010). Pá sýna rannsóknir að foreldrar upplifa merkingarbærra líf pegar peir verja tíma með börnum sínum (Musick o.fl., 2016; Nelson o.fl., 2013). Dví má segja að foreldrahlutverkið geti stuðlað að pví að foreldrar telji líf sitt merkingarbært, og pað stuðli síðan að hamingju peirra (Nelson o.fl., 2014).

Hér hefur verið greint frá premur kenningum sem varpa ljósi á upplifun feðra af hamingju. Hafa parf í huga að pessar ólíku birtingarmyndir hamingju geta skarast. Sem dæmi upplifir fólk fleiri jákvæðar tilfinningar og aukinn lífstilgang pegar pað fær sálrænum grunnpörfum sínum fullnægt (Deci og Ryan, 2004; Martela o.fl., 2017; Ryan o.fl., 2013; Ryan og Deci, 2001, 2019). Einnig stuðla jákvæðar tilfinningar að auknum lífstilgangi (Hicks og King, 2009; Martela o.fl., 2017).

Rannsóknir á hamingju foreldra sýna ólíkar og mótsagnakenndar niðurstöður, enda nálgast pær hamingju á ólíkan hátt (Nelson o.fl., 2014). Margar fyrirliggjandi rannsóknir byggjast á huglægri 
skilgreiningu og mati fólks á hamingju, par sem pátttakendur meta eigin hamingju út frá spurningunni „Hversu hamingjusamur finnst pér pú vera?“, án pess að hamingjan sé skilgreind út frá ákveðinni kenningu um hamingju (t.d. Margolis og Myrskylä, 2011). Dað er pví erfitt að átta sig á hvort eða pá hvaða kenning um hamingju liggur til grundvallar hverri rannsókn, og pað gerir jafnframt samanburð á niðurstöðum erfiðan. Dví er mikilvægt að skoða hamingju út frá ólíkum kenningarlegum sjónarhornum sem varpad geta ljósi á ólíkar birtingarmyndir hamingjunnar, eins og hér er gert. Rannsóknarspurningin sem leitað verður svara við er: Hvernig upplifa feður hamingju í tengslum við að eignast og eiga börn?

\section{Аðferð}

Til að fá innsýn í hugmyndir feðra um hamingju voru tekin hálfopin einstaklingsviðtöl við níu feður. Rannsóknin er byggð á meistaraverkefni fyrsta höfundar.

Í fyrirbærafræðilegum rannsóknum er mikilvægt að pátttakendur hafi töluverða reynslu af viðfangsefninu (Sigríður Halldórsdóttir, 2013), sem í pessu tilfelli er hamingja í föðurhlutverkinu. Pátttakendur voru valdir með hentugleikaúrtaki (Braun og Clarke, 2013). Auglýst var eftir pátttakendum á persónulegri Facebook-síðu fyrsta höfundar, par sem óskað var eftir feðrum í viðtöl til að ræða föðurhlutverkið. Auglýst var eftir feðrum sem hefðu töluverða reynslu af föðurhlutverkinu, pað er ættu tvö eða fleiri börn og pað elsta um pað bil tíu ára gamalt. Óskað var eftir feðrum sem byggju með barnsmóður sinni og ættu ekki börn úr fyrri samböndum. Баð var gert til að skilnaður og jafnvel forræðisdeilur lituðu ekki reynslu peirra. Leitast var við að helmingur feðranna byggi á höfuðborgarsvæðinu $(\mathrm{N}=4)$ og helmingur í ýmsum bæjarfélögum á landsbyggðinni $(\mathrm{N}=5)$. Feðurnir buðu sig fram til pátttöku að eigin frumkvæði eða voru hvattir til pátttöku af kunningjum sínum sem sáu auglýsinguna. Rannsakandi pekkti pátttakendur lítið sem ekkert áður en viðtölin hófust. Degar níu feður höfðu boðið sig fram til pátttöku var auglýsingin fjarlægð af Facebook.

Pátttakendur voru á aldrinum 36-55 ára, voru í sambúð eða hjónabandi með barnsmóður sinni og áttu tvö til prjú börn á aldrinum 0-13 ára. Menntunarstig peirra var ólíkt, allt frá pví að hafa lokið grunnskólaprófi til pess að hafa lokið meistaraprófi í háskóla. Allir unnu peir utan heimilis og virtust eiga pað sameiginlegt að vera í vel launuðum störfum, flestir í ábyrgðareða stjórnunarstöðu. Dátttakendurnir tilheyrðu pví hópi feðra sem líklegir eru til að vera hamingjusamir, meðal annars vegna pess að peir bjuggu með barnsmóður sinni og börnum (Nelson-Coffey, 2018) og virtust búa við fjárhagslegt öryggi (Dóra Guðrún Guðmundsdóttir, 2013).

Í viðtölunum fylgdi rannsakandi fyrir fram gerðum viðtalsvísi með opnum spurningum, en til að halda flæði í viðtölunum gat röð spurninga verið ólík. Í viðtölunum var áhersla lögð á hvernig pátttakendurnir upplifðu að eignast börn, hvernig að eiga börn hafði áhrif á daglegt líf og hvernig peir skilgreindu og upplifðu hamingju. Dá spurði rannsakandi nánar út í ýmis atriði sem komu fram í viðtalinu ef pau póttu mikilvæg fyrir rannsóknina. Viðtölin fóru fram í mars 2018, ýmist á vinnustað pátttakanda, heimili hans eða á kaffihúsi. Driðjungur viðtala fór fram í myndsímtali. Viðtölin voru 45-90 mínútur að lengd. Dau voru tekin upp á hljóðupptökutæki og afrituð orðrétt.

Farið varí einu og öllu eftir lögum um persónuvernd og meðferð persónuupplýsinga (nr. 77/2000). Pátttakendur veittu allir upplýst sampykki fyrir pátttöku í rannsókninni og vinnslu upplýsinga. Til að tryggja trúnað við pátttakendur voru peim gefin dulnefni og öllum persónugreinanlegum upplýsingum í gögnum breytt.

Gögnin voru pemagreind samkvæmt viðmiðum um fyrirbærafræðilega greiningu (Sigríður Halldórsdóttir, 2013). Hvert viðtal var marglesið og upplifun hvers pátttakanda dregin skýrt fram á greiningarblaði. Pá var hverjum pátttakanda sent sitt greiningarblað og gefið tækifæri til 
að gera athugasemdir. Svörum pátttakenda var einnig fylgt eftir með tölvupóstsamskiptum við pá til að dýpka skilning rannsakanda á efninu. Fimm pátttakendur af níu svöruðu pósti rannsakanda og gerðu engar athugasemdir við greiningarblöðin. Degar greiningarblöð höfðu verið útbúin fyrir hvern pátttakanda voru pau kóðuð með greiningarforritinu ATLAS. Dví næst var gerð tillaga að pemum út frá kóðunum og peim hamingjukenningum jákvæðrar sálfræði sem best endurspegluðu gögnin, pað er kenningu um jákvæðar tilfinningar, sjálfsákvörðunarkenningu um farsæld og sálrænar grunnparfir og kenningu um hamingju út frá auknum lífstilgangi. Kenningarnar voru nýttar til að draga fram upplifun feðranna af hamingju. Pannig voru greind fjögur meginpemu sem fjallað er um í næsta kafla.

\section{Niðurstöður og umræður}

Niðurstöður rannsóknarinnar varpa ljósi á hvernig feður upplifa hamingju í tengslum við að eignast og eiga börn. Greind voru fjögur meginpemu: 1) Hamingja sem ánægja: Lífsins lukka að eiga börn; 2) Hamingja sem farsælt líf: Manns bestu stundir eru með börnunum; 3) Hamingja sem lífstilgangur: Hamingjan er innihaldsríkari með föðurhlutverkinu; og loks 4) Lífið með börnunum er bæði krefjandi og hamingjuríkt. Demun endurspegla skilning feðranna á hamingju út frá peim kenningarlegu sjónarhornum á hamingju sem fjallað hefur verið um. Fræðilegri umræðu er fléttað saman við niðurstöðurnar.

\section{Hamingja sem ánægja: Lífsins lukka að eiga börn}

Í viðtölunum kom skýrt fram að feðurnir tengdu hamingju við jákvæðar tilfinningar eins og ánægju, gleði, stolt og pakklæti. Detta er í samræmi við umfjöllun Fredrickson (2009) um hamingju sem jákvæðar tilfinningar. Feðurnir töldu pað mikla gæfu að geta eignast börn. Eyjólfur sagði að hann hefði „örugglega getað orðið ... ósáttur og bitur ... á elliheimilinu ... ef að maður hefði ekki ... fengið að njóta pessarar gæfu“ að eignast börn. Baldur tók undir og sagði: „Detta er mikil gæfa [að eignast börn] ... pað er kannski pað sem hamingjan er.“"

Feðurnir upplifðu meiri ánægju eftir að peir eignuðust börn. Deir sögðu börnin „krydda tilveruna“ og „gefa lífinu lit“ og töluðu um að lífið með börnunum væri mun „skemmtilegra“ og ,áhugaverðara“ en líf peirra var áður. Рað er meiri gleði, „lífið snýst ... svo mikið um ... samveru og skemmtilegheit" eins og einn peirra sagði (Baldur). Friðrik talaði um að áður hefðu veraldlegir hlutir veitt honum hamingju en nú væri раð ,að [barnið læri að] pissa í klósettið ... alveg brjálæðislega skemmtilegt" og veitti hamingju. Рað samræmist fyrri rannsóknum sem hafa sýnt að í daglegu lífi upplifi foreldrar fleiri jákvæðar tilfinningar en barnlaust fólk (Deaton og Stone, 2014). Einn feðranna lýsti breytingunni eftir að hann varð faðir á pann veg að pað sem hefði áður veitt honum „,mest[a] gleði“ og „mikla hamingju og unað“ var að „standa [einn] einhvers staðar uppi í óbyggðum“ og „koma á einhverja nýja staði og upplifa eitthvað nýtt“". Eftir að hann varð faðir sagðist hann upplifa „eitthvað nýtt á hverjum degi““ (Baldur). Nokkrir feðranna töluðu um hamingjuna sem peir upplifðu áður en og eftir að peir eignuðust börnin sem tvennt ólíkt. Dannig tengdu peir föðurhlutverkið við upplifanir sem peir hefðu aldrei kynnst ef peir væru ekki feður. Friðrik sagði аð pað að eignast barn hefði verið „,mjög súrrealísk tilfinning ... alsælutilfinning ... tingling tilfinning í öllum líkamanum ... með náladofa alls staðar“. Tryggvi sagði að föðurhlutverkinu fylgdu ,tilfinningar sem að maður hafði aldrei fundið áður ... pessi sterka ... ást“, sem væri „eiginlega svona ólýsanleg“. Pannig lýstu feðurnir pví hvernig peir fundu fyrir sterkum tilfinningum ólíkt öllu pví sem peir hefðu upplifað áður.

Feðurnir töluðu mun meira um jákvæðar hliðar föðurhlutverksins en krefjandi hliðar pess. Í máli peirra mátti greina hversu ánægðir peir væru með lífið og meðvitaðir um hvað peir hefðu pað gott. Ríkharður sagði pau hjónin vera pakklát og „ótrúlega heppin“ með lífið eins og pað væri. Hann sagði: „Баð gengur allt vel hjá manni, maður ... [er] ekki með neikvæða factorinn, nema bara ... að nenna ekki að prífa eða hvað pað er.“ Feðurnir töldu sig heppna að eiga heilbrigð 
börn sem nytu velgengni. Eyjólfur sagði: „Maður er auðvitað pað lánsamur; ... okkur gekk vel að eignast börnin og pau eru heilbrigð, pau eru hraust, pau eru kát, pannig að ég hef í sjálfu sér bara upplifað kosti pess“ að vera faðir. Hamingjan veltur pó ekki einungis á jákvæðum tilfinningum (hamingja sem ánægja), heldur er hún flóknara fyrirbæri en svo að nóg sé að skilgreina hana sem ánægju (Diener o.fl., 1998; Ryan o.fl., 2008). Enda kom pað fram í greiningu gagnanna að feðurnir skilgreindu hamingjuna á fleiri vegu.

\section{Hamingja sem farsælt líf: Manns bestu stundir eru með börnunum}

Í umfjöllun feðranna um hamingju mátti greina að peir töldu hana meðal annars tengjast pví að hve miklu leyti peir gætu ráðið sér sjálfir, hvernig peir tengdust öđru fólki og hversu hæfa peir teldu sig vera til að sinna foreldrahlutverkinu. Мeð öðrum orðum pá útskýrðu peir hamingju sína út frá hversu vel peir töldu að sálrænum pörfum sínum fyrir sjálfreði, félagstengsl og hæefni væri mætt. Eins og áður hefur komið fram pá stuðlar slík upplifun að farsælu lífi (Ryan og Deci, 2017).

Feðurnir töldu sig upplifa sjálfræði pegar peir höfðu svigrúm til að sinna pví sem peim pótti mikilvægt, hvort sem pað var fjölskyldan, vinirnir eða peirra eigin parfir. Sjálfræði felur í sér að ráđa sér sjálfur og athafna sig samkvæmt eigin sannfæringu (Ingibjörg Kaldalóns, 2015; Ryan og Deci, 2017). Deir sögðu hamingjuna felast í að geta „,gert svona eiginlega mest pað sem mann langar til að gera“ (Baldur) og að pað drægi úr hamingjunni pegar peir hefðu „ekki alveg stjórn“ á sínum „tíma og ... aðstæðum“ (Eyjólfur). Einn feðranna lýsti pví pannig að hann væri betri í að „stýra ... [eigin] lífi“ eftir að hann varð faðir og sagðist vera meðvitaðri um að nýta tímann vel. Hann tengdi hamingjuna við að ,láta hlutina ekki bara gerast af sjálfu sér, heldur pað að stefna með markvissum hætti“ að einhverju (Eyjólfur). Feðurnir upplifðu pannig sjálfræði og aukna hamingju pegar peir höfðu til dæmis nægan tíma til að sinna börnum sínum. Einn feðranna, Ríkharður, upplifði mikinn sveigjanleika par sem hann eignaðist sín fyrstu börn pegar hann var í námi og taldi pað „pvílíkan lúxus“ að hafa nægan „tíma með börnunum“.

Fjárhagsstaða, sveigjanleiki í vinnu og kröfur frá samfélaginu voru meðal peirra pátta sem höfu áhrif á upplifun feðranna af sjálfræði. Aukið sjálfræði fylgdi pegar fjárhagsstaða heimilisins gerði peim kleift að vera heima með börnum sínum í fæðingarorlofi. Aukið sjálfræði fylgdi einnig sveigjanleika í vinnu til að sinna börnunum pegar pörf var á. Baldur sagði sem dæmi að hann hefði minnkað við sig vinnu eftir að hann eignaðist barn og Tryggvi sem „,vinn[ur] með föður“ sínum sagði аð раð væri „,osa mikill skilningur, ... ég fæ alltaf að hlaupa úr vinnunni“ pegar hann pyrfti. Aftur á móti upplifðu feðurnir takmarkað sjálfræði pegar peim fannst peir tilneyddir til að vinna mikið og hafa par af leiðandi minni tíma fyrir börn sín. Sjálfræði og takmarkað sjálfræði virðist pví haldast hönd í hönd 1 föðurhlutverkinu. Feðurnir gátu upplifað skort á sjálfræði pegar peir gátu ekki gert allt pað sem peir vildu gera (sjá umfjöllun um krefjandi pætti föðurhlutverksins hér á eftir), en upplifað um leið sjálfræði í ákvörðun sinni um að eignast börn og leggja sig fram við að sinna peim vel.

Hið daglega líf með börnunum stuðlar að upplifun feðranna af félagstengslum en pá upplifa peir náin tengsl við aðra og að peir séu mikilvægur hluti af samfélaginu (Ryan og Deci, 2017). Ríkharður lýsti pessu vel: „Stundum hugsar maður ... hvernig væri lífið ... ef maður væri bara einn. ... Баð eru miklu, miklu fleiri plúsar við að eiga fjölskyldu en ekki að eiga fjölskyldu.“ Аð sama skapi tengdu feðurnir samverustundir með börnunum við hamingju. Agnar sagði:

Manns bestu stundir eru með fjölskyldunni og börnunum.... Eftir að ég eignast börn, að pá er[u] ... pað [börnin] sem veit[a] mér mesta hamingju. ... Баð parf ekkert að vera að gerast ... [pví pað að vera saman], ... pað er bara hamingjustund.

Margir feðranna tengdu vellíðan fjölskyldunnar við hamingju: Pegar „öllum [í fjölskyldunni] líð[ur] vel ... pá líður manni best“ (Sindri). Ríkharður taldi að pað væri „ömurleg[t]“ að geta ekki umgengist börnin sín daglega ef maður væri til dæmis ,,[frá]skilinn“ og eingöngu ,viku og viku 
með krakkana“. Aðrir feður tóku undir með Ríkharði. Tryggvi sagði: „Баð er allt betra“ eftir að við hjónin eignuðumst börnin.

Lífið með börnunum hafði einnig áhrifá samband feðranna við barnsmóður sína. Sumir feðranna töluðu um að sambandið við barnsmóðurina hefði styrkst og proskast eftir að pau eignuðust börn. Einn peirra sagði: „Eftir að [barnið] fæddist, pá ... vorum við bæði svona all in ... og erum bara mjög ástfangin og náin í dag" (Tryggvi). Að auki hafði lífið með börnunum áhrif á samband feðranna við vini sína. Nokkrir feðranna sögðu tengslin við vinina hafa styrkst eftir að peir urðu feður - sérstaklega ef vinirnir áttu börn sjálfir. Pá hittust peir með börn sín og áttu tíma saman: „Áður en maður [varð faðir] ... hafði maður ... ekkert endilega samleið með peim félögum sem [áttu börn], ... en svo ... er maður kominn með börn“ og pá eykst samveran með peim (Baldur). Einnig voru dæmi um að samskiptin við vinina yrðu nánari eftir að peir urðu feður: „Karlmenn eru svolítið lokaðir“ en eftir að peir verða feður „fatta [peir] að pað sé hægt að tala ... um börnin og fjölskylduna og [að] pað eru allir í svipuðum málum“ (Gunnar). Um leið gat lífið með börnunum haft neikvæð áhrif á tengsl feðranna við barnsmóður sína og á sambandið við suma vini eins og fjallað verður um hér á eftir.

Hamingja feðranna endurspeglaðist í hversu hæfa peir töldu sig vera í foreldrahlutverkinu. Í pessu samhengi vísar hæfni til pess að upplifa færni í föðurhlutverkinu (Ryan og Deci, 2017). Upplifun feðranna af færni í föðurhlutverkinu var ólík eftir aldri barnsins. Đó sumir feðranna hafi upplifað sig örugga í uppeldi og umönnun barna sinna pá greindu peir einnig frá vanmæetti og óöryggi sem fjallað er um í pemanu Lifið með börnunum er bœði krefjandi og hamingjuríkt. Misjafnt var hversu hæfa feðurnir upplifðu sig til að sinna pörfum ungabarnsins, ekki síst pegar börnin voru á brjósti. Sumir feðranna voru fullir sjálfstrausts pó barnið væri á brjósti pví peir sögðust geta gert „allt annað“ en að gefa barninu brjóst. Deir feður sem áttu börn sem ekki voru á brjósti gátu jafnframt sinnt pörfum barnsins fyrir líkamlega næringu til jafns við móðurina með pví að gefa pví pela. Degar börnin urðu eldri töldu margir feðurnir sig verða enn færari í hlutverki sínu, meðal annars vegna pess að peim fannst peir geta tekið meiri pátt í umönnun barnanna. Börnin eru „miklu háðari [móðurinni] fyrst. ... [en] pegar pau eldast ... fær maður ... aðeins meira hlutverk. ... Degar [barnið] var svona tveggja ára, pá var alveg minn tími kominn" sagði Tryggvi. Aukin reynsla í föðurhlutverkinu virtist einnig auka tiltrú feðranna á hæfni sinni, eða eins og Eyjólfur sagði: „Verklegi hlutinn af pví að vera foreldri [kemur] ... bara ... með ... æfingu.“ Einnig töluðu sumir feðranna um að peir upplifðu sig sem betri uppalendur eftir pví sem peir eignuðust fleiri börn og reynslan yrði meiri. Deir töldu pað sýna að peir stæðu sig vel hversu vel börnunum vegnaði: Dau „eiga vini, eru félagslega sterk, stunda ípróttir $[\mathrm{og}]$... eru ... fyrirmyndarkrakkar“ (Ríkharður). Reynsla feðranna er í takt við að gerðar eru ólíkar kröfur til feðra eftir pví sem barnið proskast og parfir pess breytast (Azar, 2003; Palkovitz, 1996; Palkovitz og Palm, 2009).

Auk pess að fá sálrænum grunnpörfum sínum mætt er lífstilgangur mikilvægur til að upplifa hamingju (Martela og Steger, 2016). Баð kom skýrt fram í gögnunum að feðurnir tengdu lífstilgang við upplifun sína af hamingju.

\section{Hamingja sem lífstilgangur: Hamingjan er innihaldsríkari með föður- hlutverkinu}

Aukinn lífstilgangur var pað hugtak sem sást hvað skýrast í umræðu feðranna um hamingjuna. Fólki sem finnst pað hafa lífstilgang upplifir skýra stefnu og telur lífið vera skiljanlegt, rökrétt og pess virði að lifa pví (Martela og Steger, 2016). Degar feðurnir eignuðust sitt fyrsta barn upplifðu peir nýjan tilgang með lífinu. Tryggvi sagði að pegar hann eignaðist sitt fyrsta barn hefði hann fundið „,annan tilgang, einhvern æðri tilgang“ pví „pað snýst allt um [barnið]“. Hann fór að hugsa betur um sjálfan sig pví hann „elskaði lífið meira“. Gunnar sagði að sér hefði fundist pað „furðuleg breyting ... hvað pað var gott að hafa einhvern svona til að hugsa um“ og Friðrik talaði um hve gott væri að eiga börn sem treysta á mann í einu og öllu. Parna má greina aukinn lífstilgang með tilkomu barnanna, en út frá pessum frásögnum má ætla að feðurnir hafi 
upplifað í auknum mæli að lif peirra veri verðmatt og mikilvagt. Hið merkingarbæra líf, sem er eitt af undirhugtökum lífstilgangs, byggist á að upplifa að lífið sé verðmætt og mikilvægt og að pað sé pess virði að lifa pví (Martela og Steger, 2016).

Dað gæti einnig hafa aukið upplifun feðranna af merkingarbæru lífi að peir upplifðu sig mikilvæga fyrir vellíðan og framtíð barna sinna. Feðurnir töluðu um hversu vænt peim pætti um börnin og hversu „yndislegt“ væri að fylgjast með peim „vaxa og dafna“. Feðurnir voru einnig meðvitaðir um hversu mikilvægu hlutverki peir gegndu við að stuðla að hamingju barna sinna og tryggja peim góða framtíð. Gunnar sagði að markmið sitt í föðurhlutverkinu væri „,að búa til góða og heilsteypta einstaklinga“ og sjá til pess ,að pau upplifi ... hamingju og [góða] æsku“. Sindri og Friðrik sögðu sömuleiðis að pað veitti peim hamingju að geta kennt börnum sínum eitthvað og leiðbeint peim. Баð hversu mikilvæga feðurnir upplifðu sig fyrir vellíðan barna sinna sást einnig á pví að peir sögðu hamingju barnanna hafa áhrif á hamingju sína. Hafpór sagði: „Degar að börnunum gengur vel og líður vel ... pá ... hefur pað áhrif á mína hamingju ... og ef pau eru niðurbrotin að pá er ég ekki eins hamingjusamur.“ Рað hversu vel börnunum líður hefur pví áhrif á hversu mikla hamingju feðurnir upplifa.

Feðurnir töluðu með ólíkum hætti um tilgang lífsins og barneigna. Einn feðranna tengdi barneignir við líffræðilegan tilgang „að halda pessu [mannkyninu] gangandi ... og fjölga sér“ (Agnar). Annar velti fyrir sér hver „hinn eiginlegi tilgangur ... lífsins“ væri ef pað væru ekki börnin (Ríkharður). Margir peirra sögðu að pó peir hefðu áður fyrr ekki litið á pað sem tilgang sinn að eignast börn, pá væri pað tilgangur peirra nú að sinna börnunum. „Í stóra samhenginu ... [væri] allt ... svolítið pointless [án barna]. ... Detta væri rosa einfalt og litlaust og grátt líf, ef að pað væri ekki fyrir pau." Dessi orð Friðriks má tengja beint umfjöllun Martela og Steger (2016) um samhengi, sem vísar til pess að við finnum aukinn lífstilgang pegar við upplifum að við höfum skýrt hlutverk í lífinu. Að sama skapi koma pessi orð feðranna heim og saman við líkan Nelson og félaga (2014) um að foreldrar séu líklegir til að finna fyrir auknum lífstilgangi vegna barna sinna.

Upplifun feðranna af lífstilgangi sást einnig skýrt í umræðu peirra um að hamingjan væri önnur nú en hún var áđur. Deir sögðu hamingjuna sem peir upplifðu ádur en peir eignuðust börn hafa verið „,yfirborðskennd[ari]“ og jafnvel ,innihaldslaus[ari]“, á meðan hamingjan eftir að peir eignuðust börn væri fullmótaðri og innihaldsríkari. Gunnar sagðist „ekki geta borið ... pessi tvö hamingjustig saman“ pví eftir að hann eignaðist börn væri hamingjan „meira svona fullnægjandi hamingja eða ... fullskapaðri og mótaðri hamingja heldur en pað sem maður hélt að væri hamingja áður“. Баð að finna fyrir meiri lífstilgangi en áður gæti haft pau áhrif að feðurnir upplifa hamingjuna nú dýpri og innihaldsríkari.

\section{Lífið með börnunum er bæði krefjandi og hamingjuríkt}

Uvm leið og feðurnir töluðu um að lífið með börnunum veitti peim hamingju töldu peir pað einnig krefjandi. Deir sögðu раð „erfiðara“ að mörgu leyti eftir að börnin fæeddust og nefndu ýmis atriði.

Eitt af pví sem peir nefndu var uppeldi og umönnun barnanna. Deir sögðu pað geta verið krefjandi að sinna börnunum og „,reyn[t] á polinmæðina“ (Ríkharður), eins og að ,orga ekki af preytu og pirringi yfir 16 milljónustu spurningu“ barnsins um sama hlutinn (Friðrik). Annar talaði um að „,úlfatíminn, tíminn milli fimm og sjö“ væri „,krefjandi tími á öllum heimilum par sem pú ert með yngri börn“ (Eyjólfur). Enn annar talaði um morgnana sem krefjandi og sagðist alltaf vona að hann pyrfti ,ekki að berjast svona mikið við pau [börnin] á morgnana. ... Maður vill á hverjum degi að pað væri, einhvern veginn notalegra ... en við höfum ekki alveg náð pvi““ (Baldur). Nokkrir feðranna töluðu um að peim fyndist krefjandi að halda uppi aga. „Ég á svolítið erfitt með аð ... vera pessi strangi ... [pannig að] pað lendir meira á konunni minni“ sagði Tryggvi. Baldur tók undir og sagðist „ekkert [líða] vel með pað ... að vera með pessa ögun“. 
Við petta bætast öll praktísku verkefnin sem fylgja pví að vera foreldri. Friðrik talaði um álagið við að „ná að halda öllum boltunum á lofti ... [og] halda sönsum“. Рað parf að „,skutla [börnunum] út um allt“ (Friðrik). Einnig ,,parf að prífa pvottinn, ... elda matinn, ... halda heimilinu ... í standi ... [og börnin] verð[a] að læra [heima]. ... Detta daglega amstur getur verið krefjandi“ sagði Ríkharður og bætti við að heimilið væri „bara vinnustaður“. Svefnleysi var enn annað sem sumir feðranna nefndu sem neikvæða og erfiða reynslu tengda lífinu með börnunum en „undir eins og pú ert svefnlítill, pá bara styttist práðurinn og pað hefur áhrif á vinnuna og samskipti við alla“ (Eyjólfur). Svefnleysi er eitt af pví sem talið er draga úr hamingju foreldra (Nelson o.fl., 2014).

Annað sem feðurnir nefndu að væri erfitt við foreldrahlutverkið var ábyrgðin, vanmátturinn og óöryggið sem pví fylgdi. „Dú náttúrulega berð ábyrgð á ... lífi“ sem foreldri (Tryggvi) og „maður [verður] ... að standa sína plikt“ (Agnar) - ,,allan sólarhringinn“ (Baldur). Friðrik talaði um hversu „stórt og mikið hlutverk og verkefni“ föðurhlutverkið væri. Drátt fyrir að hann ætti orðið prjú börn sagði hann: „Ég held ég hafi aldrei verið tilbúinn“ pegar börnin fæeddust. „Tilfinning[in]“ er ,,alltaf“ sú að maður ,,veit ekki neitt og skilur ekki neitt og kann ekki neitt og getur ekki neitt.“ Dá talaði Gunnar um ,áhæett[una]“, „hræðsl[una]“ og „ótt[ann] við að mistakast“ eða gera eitthvað vitlaust og með pví „,skemma“ börnin sín. Feðurnir höfðu einnig áhyggjur af аð раð uppeldi sem peir veittu börnum sínum nú gerði pau ekki „,nægilega sterk til að standa í lappirnar og velja rétt" (Eyjólfur) pegar pau yrðu eldri. Í frásögnum feðranna má skýrt greina pær áhyggjur sem geta fylgt foreldrahlutverkinu (Nelson o.fl., 2014; Stickler o.fl., 1991) og pað óöryggi sem margir foreldrar upplifa nú á dögum (Bornstein, 2019).

Feðurnir upplifðu nokkrir vanmátt á fyrstu árum barnsins. Degar barnið var á brjósti upplifðu sumir peirra sig „hjálparlausa“ par sem peir gátu ekki sinnt pörfum barnsins fyrir líkamlega næringu. Friðrik sagði: „Við pabbarnir erum basically óparfir fyrstu prjá mánuðina ... algjörlega tilgangslausir ... við erum ... rosa góðir [í] að pjóna [mömmunni] ... en ... við getum ekkert [gert] fyrir börnin okkar." Vanmátturinn kom einnig skýrt fram er feðurnir töluðu um veikindi barna sinna. Раð er „erfiðast“ pví pá er „maður hjálparlaus“ og getur svo lítið gert (Agnar). „Ég held að pað yrði pað erfiðasta ef maður sæi eitthvað koma fyrir börnin sín“ sagði Eyjólfur.

Nokkrir feðranna töluðu um pann aukna kostnað sem fylgdi pví að eiga börn. „Dú parft stærra hús, pú parft stærri bíl, pannig að peningalega [séð] ... er [betta] ókostur“ sagði Ríkharður. Fjárhagsstaða fjölskyldunnar hafði einnig ráðið pví hvort peir tóku fullt fæðingarorlof eða ekki vegna launaskerðingar í fæðingarorlofi. Til dæmis sagðist Sindri aðeins hafa tekið lítinn hluta af fæðingarorlofinu pví sér hefði fundist pað ,algjör óparfi að ... bæta fjárhagsáhyggjum ... oní hitt“. Pað fjárhagslega álag sem getur fylgt pví að sjá fyrir börnunum er líklegt til að draga úr hamingju foreldra (Nelson o.fl., 2014; Stone o.fl., 2010).

Sumir feðranna töluðu um að erfitt væri að samræma vinnu og fjölskyldulíf. Eyjólfur sagði: „Skóli [barnanna], atvinnulíf, heimili - petta er ekkert hugsað saman." Sindri tók undir pað og sagði pað „ekki fjölskylduvænt að búa á Íslandi ... [pví] fólk vinnur lengi og mikið“. Eyjólfur sagði að pessi „harði vinnukúltúr“ ylli pví að „meira [væri] svona um fundi“ hjá honum ,á síðdeginu“" sem gerði pað að verkum að konan hans sækti alltaf börnin í leikskólann. Hann sagðist „ekkert alltaf sáttur við hvernig kerfið hefur verið sett upp“ en sæi „ekki alveg hvernig“ hann gæti „,breytt pví“. Agnar talaði um að mikil vinna hjá honum og „tímaleysi“ skapaði „núning á heimilinu“" pví hann væri pá „ekki til staðar“ til að sinna börnunum. Hafpór, eins og fleiri, talaði um að hann „,veri alveg til í að vera ... heima með peim [börnunum] ... allan daginn ... og gæti pá ... sinnt peim miklu betur“ en bætti svo við „,[en] pað parf líka að vinna ... og pað parf að kenna“ börnunum að „,раð purfi að hafa fyrir lífinu“. Sumir feðranna töluðu um að álagið í vinnunni hefði áhrif á samskipti peirra við börnin heima fyrir. Gunnar sagði að pað væri „sennilega mesta áskorunin“ að láta vinnuna ekki ,hafa áhrif á ... föðurhlutverkið og polinmæðina par“. Friðrik, sem sagðist vinna ,alveg ógeðslega mikið“, sagðist hafa ákveðið að minnka vinnuna til að geta sinnt börnunum betur er hann fann аð börnin voru að fjarlægjast hann. Dannig gat starfið takmarkað upplifun feðranna af sjálfræði, sem hefur áhrif á farsæld í föðurhlutverkinu. 
Feðurnir töluðu um að eftir að peir urðu feður hefði samband peirra við barnsmóður og vini breyst, um leið og frítími peirra hefði minnkað.

Dú hefur bara 24 tíma í sólarhringnum, og pú parft auðvitað að sofa ... [og] vinnan étur upp ákveðið. ... Dessi tími til að ... sinna sjálfum pér, sinna makanum ... fjölskyldu og vinum ... finnur sér nýtt jafnvægi. ... Ef pú vilt taka pátt í öllu, alltaf, með vinunum eða vinnufélögunum ... pá ertu kannski ekki ... týpan til ... að vera fjölskyldumaður (Eyjólfur).

Margir feðranna töluðu um að hafa minni tíma með barnsmóður sinni nú en áður en pau eignuðust börn: „Tíminn sem að ég og [barnsmóðirin] höfum svona saman ... er ... stundum ekki til staðar, ... [раð] koma bara margir dagar í röð sem við ... hittumst varla“ (Agnar). Pá töluðu nokkrir feðranna um aukinn ágreining í parsambandinu eftir að börnin fæddust: „Degar pú ert búinn að vera með ... krakkana heima ... pá er styttri práđurinn“ og líklegra að við verðum „eitthvað ósátt ... [hvort við] annað“ (Ríkharður). Detta er í takt við rannsóknir sem sýna að pað dragi úr ánægju í parsambandinu að eiga börn (Cui og Donnellan, 2009; Luhmann o.fl., 2012; Twenge o.fl., 2003).

Баð að eiga börn hafði einnig áhrif á tengsl feðranna við vini sína. Nokkrir feðranna töluðu um að „svona pínu ... gjá“" (Sindri) hefði myndast á milli peirra og vina peirra og í kjölfarið hefðu peir misst tengslin við pá. Pað átti sérstaklega við pegar vinirnir áttu ekki börn sjálfir. Ég „horf[i] á hlutina ... öðrum augum“ en barnlausir vinir mínir, sagði Sindri og bæetti við: „Dú ætlar ekki að [missa samband við pá], en ... pað gerist bara.“ Tryggvi sagði að „,nánustu vinir manns“ tækju pátt í lífi hans með börnunum á meðan „,peir sem eru svona kunningjar ... missti maður voða mikið samband við“. Dannig gátu pær breytingar sem fylgdu föðurhlutverkinu haft áhrif á félagstengslin.

Feðurnir töluðu um að frítími peirra hefði minnkað eftir að peir eignuðust börn. Friðrik sagði:

Frítími, hann er ekki til, hann var rosa lítill pegar við áttum eitt barn ... enginn pegar við áttum tvö börn, núna ... veit [ég] ekki hvað pað er ... [ég er sjálfur] í sextánda sæti, sirka; fyrst pau, svo er vinnan og svo er heimilið, ... síðan alls konar önnur verkefni, pá kannski kem [ég sjálfur].

Vegna takmarkaðs frítíma sagði Ríkharður: „Tíminn er miklu verðmætari en áður [en ég eignaðist börn] ... maður skipuleggur tímann miklu, miklu, miklu betur.“ Preyta hefur einnig áhrif á upplifun feðranna af frítíma. Eyjólfur sagði að pegar börnin væru sofnuð á kvöldin væri hann „svolítið latur að rífa sig aftur upp til pess að fara út, pað er undantekning að [maður hafi orku til að] gera eitthvað“. Reynsla feðranna er í samræmi við rannsóknir sem sýna að pað getur dregið úr hamingju að hafa takmarkaðan tíma (Mogilner, 2019).

Раð аð fórna eigin pörfum fyrir parfir barna sinna virðist tilheyra föðurhlutverkinu. Feðrunum pótti eðlilegt að setja börnin í fyrsta sæti, pó pað pýddi að peir gæetu ekki gert pað sem peir vildu á meðan. Börnin „eiga að vera ... númer eitt, tvö og prjú“ (Tryggvi). Deim pótti mun mikilvægara að sinna börnum sínum en að njóta pess frelsis sem peir upplifðu ádur en peir urðu feður. Aðrir feður töluðu um pessa forgangsröðun í págu barnanna sem tímabundna, pví „,pegar tímabilið kemur, par sem börnin eru sjálfstæð og purfa ekki á mér að halda, ... fæ ég útrás fyrir eitthvað sem ... ég hefði kannski viljað gera núna“ (Eyjólfur). Dví má segja að föðurhlutverkinu fylgi hamingja prátt fyrir pær áskoranir sem fylgja pví. Mögulega er pað pó vegna pessara áskorana sem feðurnir upplifa hamingjuna. Að áskoranirnar sem fylgja pví að sinna börnum sínum geri lífið innihaldsríkara en ádur. 


\section{Samantekt og lokaorð: Hamingjan með börnunum er önnur en áour}

Feðurnir töluðu um hamingjuna sem peir upplifðu áður og eftir að peir eignuðust börnin sem tvennt ólíkt. Dannig tengdu peir föðurhlutverkið við upplifanir sem peir hefðu aldrei kynnst ef peir væru ekki feður; djúpstæða gleði og ást. Dá kom fram í frásögnum feðranna að peir upplifðu aukinn lífstilgang eftir að peir eignuðust börnin. Börnin skiptu „öllu máli“ “ ́ lífi peirra og peir upplifðu að peir skiptu afar miklu máli í lífi barna sinna. Dar með varð líf peirra, ákvarðanir og athafnir allt svo miklu mikilvægara en áður en börnin komu til sögunnar.

Hamingjan eftir að feðurnir eignuðust börn var pví að peirra sögn innihaldsríkari. Deir töluðu um að hamingjan ætti upptök sín annars staðar núna en áður. Tryggvi sagði:

Ég held ég hafi bara ekki vitað hvað hamingja var, áður en pau [börnin] fæddust. ... Ég held pað hafi bara verið einhver ... yfirborðskennd hamingja, ... að kaupa sér nýjan síma eða ... fara á djammið.... Рað er ekkert hægt að bera petta saman.

Mögulegt er að hamingjan sem peir upplifðu áður hafi í ríkari mæli falist í stundargleði. Eftir að peir eignuðust börn breyttist lífið mikið og peir fundu aukinn lífstilgang við pað eitt að upplifa lífið með börnunum. Feðurnir voru sammála um að áskoranirnar sem fylgdu föðurhlutverkinu væru pess virði. Ríkharður orðaði petta vel og sagði að prátt fyrir að hann hefði „miklu“ minna „á milli handanna“, pyrfti að „,prífa stærra hús“ og að pau hjónin hefðu „ekki ... mikinn tíma fyrir hvort annað“ pá væri pað „ekkert sem hefur áhrif á hamingjuna“. Dví „,pó að pað reyni á núna ... skiptir [pað] ekki máli pegar maður horfir á heildarmyndina“.

Af gögnunum má sjá að pað var margt sem gerði líf feðranna með börnum sínum krefjandi og gerði раð аð verkum að peir upplifðu síður að sálrænum grunnpörfum peirra fyrir sjálfræði, félagstengsl og hæfni væri mætt. Ytri pættir eins og vinnutími setti sjálfræði peirra skorður. Á tímabilum upplifðu peir einnig vanmátt við umönnun barnanna og minni tengsl við barnsmóður og vini. Upplifun feðranna af pví hvernig grunnpörfum peirra var mætt var pó mismunandi eftir aðstæðum. Í pemanu um hamingju sem farsæld voru nefnd dæmi um hvernig feðurnir upplifðu sjálfræði og sjálfstiltrú í umönnun barna sinna. Einnig voru dæmi um að tengsl við vini og barnsmæður væru dýpri. Lífið með börnunum virðist pví bæði geta stuðlað að pví að feðurnir fái sálrænum grunnpörfum sínum fullnægt og komið í veg fyrir pað.

Ánægjan og hamingjan sem börnin veita feðrum sínum er líkleg til að bæta upp fyrir pað hversu krefjandi lífið með peim er. „Öll pessi litlu svona bjánalegu moment“, pegar börnin eru búin „að rífast og orga og grenja ... og svo kemur eitt bros [frá peim] og pá ... gufa upp ... síðustu sjö mánuðir af veseni““ (Friðrik). Tilfinningalega ,jójó-ið verður meira“ eftir að börnin komu til sögunnar, eins og Hafpór sagði. Hann lýsti pví svo að nú væru fleiri pættir sem hefðu áhrif á hamingju hans, pað væru meiri líkur á ,að eitthvað dragi mann niður“ og einnig líklegra að eitthvað „hífi mann upp“ (Hafpór). Раð er í takt við að foreldrahlutverkinu fylgi bæði fleiri jákvæðar og fleiri neikvæðar tilfinningar (Deaton og Stone, 2014). Feðurnir voru pví sammála um að börnin „veita manni svo mikla hamingju, ... [bó pau] séu stundum erfið“ (Tryggvi).

Á heildina litið töldu feðurnir lífið með börnunum mun betra en lífið án peirra. Рað að sinna börnunum var, að peirra mati, peirra stærsta verkefni pví „maður [er] ... pabbi númer eitt, tvö og prjú í dag ... og svo hitt“ eins og Agnar sagði. Feðurnir sögðu pað einstaka upplifun að fá að ala upp börn sín og sjá pau proskast og dafna. Deir voru pakklátir fyrir að fá að lifa lífinu með börnum sínum.

Niðurstöðurnar eru mikilvægt framlag til rannsókna á hamingjunni innan jákvæðrar sálfræði sem og rannsókna á upplifun feðra af hlutverki sínu. Dó ber að hafa í huga að viðmælendur rannsóknarinnar bjuggu allir við ýmis forréttindi, svo sem fjárhagslegt öryggi. Dá bjuggu peir allir á Íslandi, með barnsmóður sinni og börnum. Dessir pættir eru allir taldir líklegir til að auka 
hamingju. Mikilvægt er pví að skoða reynslu feðra sem ekki njóta sömu forréttinda og gætu pví haft ólíka upplifun af föðurhlutverkinu og hamingjunni. Enda hafa fræðimenn bent á að pegar fólk býr við erfiðar félagslegar aðstæður séu barneignir líklegri til að gera aðstæður peirra meira krefjandi en ella og draga úr hamingju pess (Dolan o.fl., 2008).

\section{Pakkarorð}

Við færum feðrunum pakkir fyrir pátttökuna og hversu einlægir peir voru í viðtölunum. Einnig pökkum við Önnu Lilju Einarsdóttur og Lóu Guðrúnu Gísladóttur fyrir aðstoð við textavinnu.

\section{"I don't think I knew what happiness was until they were born": Fathers' experience of happiness}

There is limited research available on how having children impacts fathers' sense of happiness. Despite evidence suggesting that fathers experience vast happiness in their role, findings on parental happiness show conflicting results. Some studies show that having children increases parents' happiness while others maintain that the process might reduce parents' level of happiness. The aim of this study was to increase understanding of how fathers experience happiness through fatherhood. A phenomenological approach was used and interviews taken with nine fathers. They had between two and three children each, aged 13 and younger, and lived with the mother of their children. Participants belonged to a group of fathers who were likely to experience high levels of happiness, partly because they lived with their children and their children's mother and they seemed to enjoy sufficient financial security. The study looked at the fathers' definition of happiness, framed within three happiness theories: theory of positive emotions, self-determination theory about eudaimonia and basic psychological needs, and theory of meaning in life.

The findings showed that the fathers experienced happiness differently after their children were born. They reported an increase of positive emotions compared to before, deep-felt love, joy and gratitude. They also described a strengthened sense of meaning in their life following the birth of their children, expressing that their happiness had become richer and more meaningful. As a result, their life, decisions and actions began to take on a more important meaning after the children arrived in the world.

Despite the happiness-filled life with their children, the fathers found the role challenging and, in many ways, more difficult, as they sought to raise and care for their children, grapple with all the practical tasks accompanying parenthood, coordinate work and family life, as well as having enough time to spend with their partner, friends and hobbies. The fathers also experienced powerlessness and insecurity, for example when they felt there was but little they could do for their children when they fell ill. They also expressed concerns about their lack of competence in the parental role, given they were now responsible for their children's well-being.

The study suggests that the fathers' happiness was related to the degree of autonomy they experienced in their role, how competent they felt in their parental role and in bonding with their children - that is, the extent to which their basic psychological needs were met. It is likely that the fathers experienced a lack of autonomy when they had to prioritize work over their children. It is also possible to surmise that their need for relatedness was insufficiently met if they felt there was little time to spend with their partner or their friends. Finally, it is possible to argue that the fathers felt 
less competent when faced with feelings of powerlessness and insecurity in relation to childrearing. At the same time, the fathers are likely to experience increased autonomy, relatedness, and competence when they have ample time to spend with their children, their partner and their friends and feel competent in their parenting role at the same time. The role of parenthood, therefore, created conditions in which the fathers' basic psychological needs were met, but the reverse was also the case.

In general, the challenges of parenthood were much less significant when compared to the level of happiness the children brought them. The fathers agreed that the challenges of fatherhood were worth the effort. The joy and happiness of the role compensates for how demanding it can be. They also noted that the source of happiness was different from what it used to be. Before becoming fathers, the happiness they experienced was more superficial and even more meaningless, whereas the happiness they felt in their role as fathers was fuller and more meaningful. It is possible that their previous experiences of happiness had more to do with short-term gratification. Their life changed radically after becoming fathers, a life where the children gave them a stronger sense of meaning. In sum, the fathers claimed that their life was considerably better with their children than without them. The fathers said that raising their children was a unique experience; seeing them grow and flourish. They were grateful for having the opportunity to live a life shared with their children.

The authors are unaware of previous research focusing on fathers' sense of happiness in the manner conducted in the current study. The study is an important contribution to happiness research within the field of positive psychology as well as a study on fathers' experience of their role.

Key words: happiness, happiness theories, fathers, role of the father, phenomenology.

\section{Um höfunda}

Pála Margrét Gunnarsdóttir (pmg@hi.is) er aðjunkt í uppeldis- og menntunarfræði á Menntavísindasviði Háskóla Íslands. Pála Margrét lauk BA-prófi í uppeldis- og menntunarfræði (2016) og MA-prófi í foreldrafræðslu og uppeldisráðgjöf (2019) frá Háskóla Íslands. Meistaraverkefni Pálu Margrétar fjallaði um hvernig feður upplifa að eignast og eiga börn og hvernig sú upplifun tengist auknum proska, hamingju og lífstilgangi, út frá kenningum jákvæðrar sálfræði. Dessi grein er byggð á niðurstöðum meistaraverkefnisins.

Ingibjörg V. Kaldalóns (ingakald@hi.is) er lektor við Menntavísindasvið Háskóla Íslands. Hún lauk BA-prófi í stjórnmála- og félagsfræði frá Félagsvísindadeild Háskóla Íslands árið 1993, MA-gráđu í félagsfræði frá sömu deild 1996 og doktorsprófi frá Menntavísindasviði Háskóla Íslands árið 2015. Í rannsóknum sínum hefur Ingibjörg einkum beint sjónum að starfsháttum í grunnskólum, pátttöku, sjálfræði og prautseigju nemenda í skólastarfi sem og velfarnaði nemenda og kennara.

Hrund Dórarins Ingudóttir (hrundin@hi.is) er lektor í uppeldis- og menntunarfræði á Menntavísindasviði Háskóla Íslands. Hrund lauk bakkalárprófi (2006), meistaraprófi (2008) og doktorsprófi (2015) í uppeldis- og menntunarfræði frá Háskóla Íslands. Hrund stundaði nám í foreldrafræðslu og uppeldisráðgjöf við University of Minnesota sem hluta af doktorsnámi sínu. Helstu rannsóknarsvið Hrundar eru uppeldissýn foreldra sem og próun foreldrafræðslu og uppeldisráðgjafar á Íslandi. 


\section{About the authors}

Pála Margrét Gunnarsdóttir (pmg@hi.is) is an adjunct in education studies at the School of Education, University of Iceland. Pála Margrét completed a BA degree in education studies (2016) and an MA in parent education (2019) from the University of Iceland. Her MA thesis focused on how fathers experience having children, in relation to adult development, happiness and meaning in life, from the scope of positive psychology. This research article is based on the findings from that thesis.

Ingibjörg V. Kaldalóns (ingakald@hi.is) is an assistant professor at the School of Education, University of Iceland. She completed a BA degree in political science in 1993 from the Faculty of Social Sciences at the University of Iceland and an MA degree in sociology in 1996 from the same faculty. She has a PhD degree in education since 2015, from the School of Education, University of Iceland. Her research is in the field of school practices that support teachers' and students' empowerment, resilience and well-being.

Hrund Dórarins Ingudóttir (hrundin@hi.is) is an assistant professor in education studies at the School of Education, University of Iceland. Hrund completed her BA degree (2006), an MA degree (2008) and a Ph.D. (2015) in education studies from the University of Iceland. She studied parent education at the University of Minnesota as a part of her doctoral thesis. Her research focuses on parents' pedagogical vision and the development of parent education in Iceland.

\section{Heimildir}

Aassve, A., Goisis, A. og Sironi, M. (2012). Happiness and childbearing across Europe. Social Indicators Research, 108(1), 65-86. https://doi.org/10.1007/s11205-011-9866-x

Andrea Hjálmsdóttir og Valgerður S. Bjarnadóttir. (2021). "I have turned into a foreman here at home": Families and work-life balance in times of COVID-19 in a gender equality paradise. Gender, Work E Organization, 28(1), 268-283. https://doi.org/10.1111/gwao.12552

Azar, S. T. (2003). Adult development and parenthood. Í J. Demick og C. Andreoletti (ritstjórar), Handbook of adult development (bls. 391-415). Springer.

Ásdís Aðalbjörg Arnalds, Guðný Björk Eydal og Ingólfur V. Gíslason. (2013). Equal rights to paid parental leave and caring fathers - the case of Iceland. Stjórnmál og stjórnsýsla, 9(2), 323-344. https://doi. org/10.13177/irpa.a.2013.9.2.4

Ásdís Aðalbjörg Arnalds, Guðný Björk Eydal og Ingólfur V. Gíslason. (2015). Fæðingarorlof og pátttaka feðra í umönnun barna sinna premur árum eftir fæðingu fyrsta barns. Í Halldór Guðmundsson og Sigrún Harðardóttir (ritstjórar), Djóðarspegillinn: Rádstefna í félagsvísindum XVI (bls. 1-9). Háskóli Íslands, Félagsráđgjafardeild.

Ásta Jóhannsdóttir og Ingólfur V. Gíslason. (2018). Young Icelandic men’s perception of masculinities. The Journal of Men's Studies, 26(1), 3-19. https://doi.org/10.1177/1060826517711161

Balbo, N. og Arpino, B. (2016). The role of family orientations in shaping the effect of fertility on subjective well-being: A propensity score matching approach. Demography, 53(4), 955-978. https://doi.org/10.1007/ s13524-016-0480-z

Baranowska, A. og Matysiak, A. (2011). Does parenthood increase happiness? Evidence for Poland. Vienna Yearbook of Population Research, 9, 307-325. https://doi.org/10.1553/populationyearbook2011s307

Borisenko, J. (2007). Fatherhood as a personality development factor in men. The Spanish Journal of Psychology, 10(1), 82-90. https://doi.org/10.1017/S1138741600006338 
Bornstein, M. H. (2019). Preface to the third edition. Í M. H. Bornstein (ritstjóri), Handbook of parenting: Volume 1: Children and parenting (3. útgáfa, bls. ix-xiii). Routledge.

Braun, V. og Clarke, V. (2013). Successful qualitative research: A practical guide for beginners. SAGE.

Craig, L. (2006). Does father care mean fathers share?: A comparison of how mothers and fathers in intact families spend time with children. Gender and Society, 20(2), 259-281. https://doi. org/10.1177/0891243205285212

Cui, M. og Donnellan, M. B. (2009). Trajectories of conflict over raising adolescent children and marital satisfaction. Journal of Marriage and Family, 71(3), 478-494. https://doi.org/10.1111/j.1741-3737.2009.00614.x

Deaton, A. og Stone, A. A. (2014). Evaluative and hedonic wellbeing among those with and without children at home. Proceedings of the National Academy of Sciences, 111(4), 1328-1333. https://doi.org/10.1073/ pnas.1311600111

Deci, E. L. og Ryan, R. M. (2000). The „what“ and „why“ of goal pursuits: Human needs and the selfdetermination of behavior. Psychological Inquiry, 11(4), 227-268. https://doi.org/10.1207/ S15327965PLI1104_01

Deci, E. L. og Ryan, R. M. (2004). Overview of self-determination theory: An organismic dialectial perspective. Í E. L. Deci og R. M. Ryan (ritstjórar), Handbook of self-determination research (bls. 3-33). University of Rochester.

Diener, E., Sapyta, J. J. og Suh, E. (1998). Subjective well-being is essential to well-being. Psychological Inquiry, 9(1), 33-37. https://doi.org/10.1207/s15327965pli0901_3

Diener, E., Wirtz, D., Biswas-Diener, R., Tov, W., Kim-Prieto, C., Choi, D. og Oishi, S. (2009). New measures of well-being. Í E. Diener (ritstjóri), Assessing well-being: The collected works of Ed Diener (bls. 247-266). Springer Netherlands. https://doi.org/10.1007/978-90-481-2354-4_12

Dolan, P., Peasgood, T. og White, M. (2008). Do we really know what makes us happy? A review of the economic literature on the factors associated with subjective well-being. Journal of Economic Psychology, 29(1), 94-122. https://doi.org/10.1016/j.joep.2007.09.001

Dóra Guðrún Guðmundsdóttir. (2013). The impact of economic crisis on happiness. Social Indicators Research, 110(3), 1083-1101. https://doi.org/10.1007/s11205-011-9973-8

Eiríkur Ingi Björnsson og Sigríður Halldórsdóttir (dagskrárgerð). (2017, 12. nóvember). Avvi [sjónvarpspáttur, nr. 3]. RÚV.

Fredrickson, B. L. (2009). Positivity: Groundbreaking research reveals how to embrace the hidden strength of positive emotions, overcome negativity, and thrive. Crown.

George, L. S. og Park, C. L. (2016). Meaning in life as comprehension, purpose and mattering: Toward integration and new research questions. Review of General Psychology, 20(3), 205-220. https://doi. org/10.1037/gpr0000077

Hansen, T. (2012). Parenthood and happiness: A review of folk theories versus empirical evidence. Social Indicators Research, 108(1), 29-64. https://doi.org/10.1007/s11205-011-9865-y

Helliwell, J. F., Layard, R. og Sachs, J. (2017). World happiness report 2017. https://worldhappiness.report/ ed/2017/

Helliwell, J. F., Layard, R., Sachs, J. og De Neve, J.-E. (2021). World happiness report 2021. https:// worldhappiness.report/ed/2021/

Hicks, J. A. og King, L. A. (2009). Positive mood and social relatedness as information about meaning in life. The Journal of Positive Psychology, 4(6), 471-482. https://doi.org/10.1080/17439760903271108

Hrund Dórarins Ingudóttir. (2015). Fathers' pedagogical vision: A phenomenological study [doktorsritgerð, Háskóli Íslands]. http://hdl.handle.net/1946/21892

Ingibjörg Kaldalóns. (2015). Stuðningur við sjálfreði nemenda í islenskum grunnskólum [doktorsritgerð, Háskóli Íslands]. http://hdl.handle.net/1946/23308

Knee, C. R. og Uysal, A. (2011). The role of autonomy in promoting healthy dyadic, familial, and parenting relationships across cultures. Í V. I. Chirkov, R. M. Ryan og K. M. Sheldon (ritstjórar), Human autonomy in cross-cultural context: Perspectives on the psychology of agency, freedom, and well-being (bls. 95-110). Springer Netherlands. https://doi.org/10.1007/978-90-481-9667-8_5 
Kohler, H.-P., Behrman, J. R. og Skytthe, A. (2005). Partner + children = happiness? The effects of partnerships and fertility on well-being. Population and Development Review, 31(3), 407-445. https://doi. org/10.1111/j.1728-4457.2005.00078.x

Lambert, N. M., Stillman, T. F., Baumeister, R. F., Fincham, F. D., Hicks, J. A. og Graham, S. M. (2010). Family as a salient source of meaning in young adulthood. The Journal of Positive Psychology, 5(5), 367-376. https://doi.org/10.1080/17439760.2010.516616

Luhmann, M., Hofmann, W., Eid, M. og Lucas, R. E. (2012). Subjective well-being and adaptation to life events: A meta-analysis. Journal of Personality and Social Psychology, 102(3), 592-615. https://doi.org/10.1037/ a0025948

Lög um fæðingar- og foreldraorlof nr. 95/2000.

Lög um persónuvernd og meðferð persónuupplýsinga nr. 77/2000.

Margolis, R. og Myrskylä, M. (2011). A global perspective on happiness and fertility. Population and Development Review, 37(1), 29-56. https://doi.org/10.1111/j.1728-4457.2011.00389.x

Martela, F., Ryan, R. M. og Steger, M. F. (2017). Meaningfulness as satisfaction of autonomy, competence, relatedness, and beneficence: Comparing the four satisfactions and positive affect as predictors of meaning in life. Journal of Happiness Studies, 19(5), 1261-1282. https://doi.org/10.1007/s10902-017-9869-7

Martela, F. og Steger, M. F. (2016). The three meanings of meaning in life: Distinguishing coherence, purpose, and significance. The Journal of Positive Psychology, 11(5), 531-545. https://doi.org/10.1080/1 7439760.2015 .1137623

Maskína. (2019). Lifshamingja. https://maskina.is/wp-content/uploads/2019/03/2019_03_Hamingja_ Mask\%C3\%ADnusk\%C3\%BDrsla.pdf

Mogilner, C. (2019). It's time for happiness. Current Opinion in Psychology, 26, 80-84. https://doi.org/10.1016/j. copsyc.2018.07.002

Musick, K., Meier, A. og Flood, S. (2016). How parents fare: Mothers' and fathers' subjective well-being in time with children. American Sociological Review, 81(5), 1069-1095. https://doi. org/10.1177/0003122416663917

Myers, D. G. og Diener, E. (2018). The scientific pursuit of happiness. Perspectives on Psychological Science, 13(2), 218-225. https://doi.org/10.1177/1745691618765171

Nelson, S. K., Kushlev, K., English, T., Dunn, E. W. og Lyubomirsky, S. (2013). In defense of parenthood: Children are associated with more joy than misery. Psychological Science, 24(1), 3-10. https://doi. org/10.1177/0956797612447798

Nelson, S. K., Kushlev, K. og Lyubomirsky, S. (2014). The pains and pleasures of parenting: When, why, and how is parenthood associated with more or less well-being? Psychological Bulletin, 140(3), 846-895. https://doi.org/10.1037/a0035444

Nelson-Coffey, S. K. (2018). Married ... with children: The science of well-being in marriage and family life. Í E. Diener, S. Oishi og L. Tay (ritstjórar), Handbook of well-being (bls. 422-436). DEF.

Nelson-Coffey, S. K., Killingsworth, M., Layous, K., Cole, S. W. og Lyubomirsky, S. (2019). Parenthood is associated with greater well-being for fathers than mothers. Personality and Social Psychology Bulletin, 45(9), 1378-1390. https://doi.org/10.1177/0146167219829174

Nordenmark, M. (2018). The importance of job and family satisfaction for happiness among women and men in different gender regimes. Societies, 8(1), 1. https://doi.org/10.3390/soc8010001

Palkovitz, R. (1996). Parenting as a generator of adult development: Conceptual issues and implications. Journal of Social and Personal Relationships, 13(4), 571-592. https://doi.org/10.1177/0265407596134006

Palkovitz, R., Marks, L. D., Appleby, D. W. og Holmes, E. K. (2003). Parenting and adult development: Contexts, processes, and products of intergenerational relationships. Í L. Kuczynski (ritstjóri), Handbook of dynamics in parent-child relations (bls. 307-324). SAGE.

Palkovitz, R. og Palm, G. (2009). Transitions within fathering. Fathering, 7(1), 3-22. https://doi.org/10.3149/ fth.0701.03 
Ryan, R. M., Curren, R. R. og Deci, E. L. (2013). What humans need: Flourishing in Aristotelian philosophy and self-determination theory. Í A. S. Waterman (ritstjóri), The best within us: Positive psychology perspectives on eudaimonia (bls. 57-75). American Psychological Association.

Ryan, R. M. og Deci, E. L. (2000). Self-determination theory and the facilitation of intrinsic motivation, social development, and well-being. American Psychologist, 55(1), 68-78.

Ryan, R. M. og Deci, E. L. (2001). On happiness and human potentials: A review of research on hedonic and eudaimonic well-being. Annual Review of Psychology, 52(1), 141-166. https://doi.org/10.1146/ annurev.psych.52.1.141

Ryan, R. M. og Deci, E. L. (2011). A self-determination theory perspective on social, institutional, cultural, and economic supports for autonomy and their importance for well-being. Í V. I. Chirkov, R. M. Ryan og K. M. Sheldon (ritstjórar), Human autonomy in cross-cultural context: Perspectives on the psychology of agency, freedom, and well-being (bls. 45-64). Springer Netherlands. https://doi.org/10.1007/978-90-481-9667-8_3

Ryan, R. M. og Deci, E. (2014). Self-determination theory. Í A. C. Michalos (ritstjóri), Encyclopedia of quality of life and well-being research (bls. 5755-5760). Springer. https://doi.org/10.1007/978-94-007-07535_2630

Ryan, R. M. og Deci, E. L. (2017). Self-determination theory: An introduction and overview. Í Selfdetermination theory: Basic psychological needs in motivation, development, and wellness (bls. 3-25). Guilford.

Ryan, R. M. og Deci, E. L. (2019). Brick by brick: The origins, development, and future of self-determination theory. Í A. Elliot (ritstjóri), Advances in motivation science, 6(111-156). https://doi.org/10.1016/bs. adms.2019.01.001

Ryan, R. M., Huta, V. og Deci, E. L. (2008). Living well: A self-determination theory perspective on eudaimonia. Journal of Happiness Studies, 9(1), 139-170. https://doi.org/10.1007/s10902-006-9023-4

Siedlecki, K. L., Salthouse, T. A., Oishi, S. og Jeswani, S. (2014). The relationship between social support and subjective well-being across age. Social Indicators Research, 117(2), 561-576. https://doi.org/10.1007/ s11205-013-0361-4

Sigríður Halldórsdóttir. (2013). Fyrirbærafræði sem rannsóknaraðferð. Í Sigríður Halldórsdóttir (ritstjóri), Handbók í aðferðafreði rannsókna (bls. 281-297). Háskólinn á Akureyri.

Stickler, G. B., Salter, M., Broughton, D. D. og Alario, A. (1991). Parents' worries about children compared to actual risks. Clinical Pediatrics, 30(9), 522-528. https://doi.org/10.1177/000992289103000901

Stone, A. A., Schwartz, J. E., Broderick, J. E. og Deaton, A. (2010). A snapshot of the age distribution of psychological well-being in the United States. Proceedings of the National Academy of Sciences, 107(22), 9985-9990. https://doi.org/10.1073/pnas.1003744107

Thompson, R., Lee, C. og Adams, J. (2013). Imagining fatherhood: Young Australian men's perspectives on fathering. International Journal of Men's Health, 12(2), 150-165. https://doi.org/10.3149/jmh.1202.150

Twenge, J. M., Campbell, W. K. og Foster, C. A. (2003). Parenthood and marital satisfaction: A metaanalytic review. Journal of Marriage and Family, 65(3), 574-583. https://doi. $\operatorname{org} / 10.1111 / \mathrm{j} .1741-3737.2003 .00574 . x$

World Economic Forum. (2021). Global gender gap report 2021. http://www3.weforum.org/docs/WEF_ GGGR_2021.pdf

Dóra Kristín Dórisdóttir og Kolbeinn Stefánsson. (2010). Verkaskipting kynjanna fyrir og eftir bankahrun. Karlar verja meiri tíma í heimilisstörf en peir gerðu árið 2005. Fréttabréf Djóðmálastofnunar, 10. http://hdl. handle.net/10802/696

Pála Margrét Gunnarsdóttir, Ingibjörg V. Kaldalóns og Hrund Dórarins Ingudóttir. (2021).

„Ég held ég hafi bara ekki vitað hvað hamingja var áður en pau fæddust“: Upplifun feðra af hamingju

Netla - Veftímarit um uppeldi og menntun. Menntavísindasvið Háskóla Íslands.

Sótt af http://netla.hi.is/greinar/2021/alm/17

DOI: https://doi.org/10.24270/netla.2021.17 